without it. Whether we are to consider that Coral growth began earlier in England than in France, or that Cidaris florigemma reached us later, is an interesting question; but this much is certain, that the Coral growths continued to a much later period in Eastern France; hence the idea that Cidaris forigemma is indicative of a low Corallian horizon. In the discussion on oụr paper, Professor Morris pointed out that " the so-called Corallian occupied different zones in different localities on the Continent, stretching, in fact, from the Oxfordian to the Portlandian inclusive." Correlation, to be of any value, therefore, is only to be effected by a detailed examination of both the English and continental areas, without confounding together either the beds of different districts, or those of the same district, as is generally done in all works dealing with the subject.

Londow, Dec. 6, 1877.

Blake and Hudueston.

P.S. The great stretch of country passed under review in the "Corallian Rocks of England" obliged us to condense lists of fossils as much as possible. Had we given a full list of fossils from the North Pit, it is difficult to see that any doubt as to its age could exist. The following, omitting certain indefinite forms, is as full a list as we have been able to put together:

Ammonites perarmatus
"Nitiorina muricata (var.)
Pleurotomaria (cast)
Gervillia aviculoides
Opis Phillipsi

Only three of these occur in the South Pit.

\author{
Isocardia (cast) \\ Pygaster umbrella \\ Eehinobrissus scutatus \\ Holectypus depressus \\ Collyrites bicordatus
}

\title{
CYCADACEOUS PLANTS OF THE DAMUdas.
}

Srr,-I beg you will allow me space to correct some erroneous impressions that might be made by certain not sufficiently explained statements published by me in the Grologrcal Magazine, and elsewhere, and to apologize to the gentlemen whom I thereby have had the misfortune to offend. I beg to state that any such effect was as far from my intention as it certainly would be contrary to my interests, and I regret that, when stating facts, I did not more fully notice circumstances that wopld only be known to those immediately concerned.

The following instances will sufficiently explain this unfortunate misunderstanding.

When writing in the Grologros c Magazing in November, 1876, p. 489, on the occurrence of Cycadeaceous plants in the Damudas, saying in footnote No. 10 "that they were known long ago," I ought to have explained that the two species (out of three) I mentioned, i.e. Noggerathia, near Vogesiaca and Glossozamites, although collected some years since, have not before been determined as such, and only Nöggerathia? Hislopi was by its describer (Sir Ch. Bunbury) considered as donbtfully Cycadeaceous, and I see now that my footnote, No. 10, should bave been written thus: "that Cycadeaceous plants 
were collected-but not described," for which I beg to apologize to Mr. W. T. Blanford.

Mr. W. T. Blanford's remark "that Cycads have not hitherto been found in the Damudas" was therefore in so far correct as the mentioned specimens, with the exception of Nöggerathia? Hislopi, althongh found have hitherto not been determined until I did so.

I should also, when writing in the September Number of the GroL. Mag. 1877, p. 431, that "Zamia Burdwanensis, McClell., has been described as long ago as 1850," have added that the affinities of this species had been later disputed for many years, Dr. Oldham supposing, from the material at his disposal, that a Schizoneura has been mistaken for a Zamia, until, through the recovery of the original specimen, this species was proved to be indeed a Zamia. (I described this species fully, with its history, in Reo. Geol. Surv. of India, 1877, vol. x. No. 2.)

I wrote in the November Number of the GeoL. Mag. 1876, already referred to: "From the occurrence of the genus Glossopteris in these beds (Danudas), they have been for a long time brought into oonnexion with the Australian Coal-measures, and declared without any proof as probably Palæozoic," and I referred to Dr. Oldham, Mr. H. T. Blanford, and Mr. W. T. Blanford as authorities. This was the impression left upon me after the perusal of the papers referred to-but 'I should have explained that besides Glossopteris, some other fossil plants also were mentioned as correlating fossils. I express my regret for having left these other correlations unconsidered, but I hope to be able to explain this point further in the Flora of the Lower Gondwanas in India. This note refers to all my publications on this subject. Otrokar Feistmantel.

CALCUTTA, Oct. 9, 1877.

\section{PROFESSOR MILNe AND THE GLacial PHeNomena OF SCANDINAVIA.}

SrR,-It is not without great astonishment that I-and, I think, most geologists who have devoted any attention to the post-Tertiary formations of Northern Europe-have read a paper by Professor John Milne in your last July Number. ${ }^{1}$. By some observations made from the railway waggon, or the steamer, when travelling through Sweden and Finland, he thinks himself enabled to refute the views since many years universally held by Scandinavian geologists respecting the surface geology of the country. The features usually attributed to the action of glaciers on a continental ice-sheet-as, for instance, the polished and scratched rocks and the boulders-he thinks better explained by the action of coast-ice. If Professor Milne had stayed a day in Sweden, and made an excursion with a Swedish geologist, I hardly doubt that the first part of his Travelling Notes would have been unwritten, for it seems impossible that a person with such good reasoning powers should hold the views advocated in those notes, after seeing a few of these scratched rocks

1 J. Milne: Across Europe and Asia. Travelling Notes. Part I. London to St. Petersburg. Grol. Maa. Dec. II. Vol. IV. p. 289 seq. 